\title{
Études seiziémistes*
}

\author{
BODO L.O. RICHTER
}

Robert Aulotte's brief, touching necrology of V.-L. Saulnier in BHR, XLIII, 3 (1981) makes us feel even more strongly the loss of this great scholar and teacher. Saulnier lived to receive, on May 30,1980, the homage volume under review here, but with little time to spare as he died that September. Thus these Études became a memorial all too soon. It is part of " 'la grande flotte' de ses disciples" (BHR, p. 577) that is sailing past here, paying tribute.

The twenty-nine studies gathered are grouped under five major headings: I "Aspects de la vie intellectuelle"; II "Aspects de la littérature narrative"; III "Aspects de la poésie en France"; IV "Les Lettres à l'écoute du monde et des événements"; and V, in a perhaps disadvantageously placed coda on a single author, "Lectures de Montaigne," which comprises only three contributions. Sections II and III have their own subdivisions while I and IV obviously allow the greatest diversity of subject matter.

Charles Béné (Grenoble-III) opens the proceedings with a major topic which is not easily accommodated within the narrow confines of fourteen pages, "Culture humaniste et culture médiévale." The aim: "L'objet de la présente étude sera de montrer que la plupart des représentants de la pensée humaniste ont gardé les mêmes maîtres de pensée ..." (p. 5). The authority of the Church Fathers, especially Saint Augustine and Saint Jerome, reigned supreme and the core of Béné's survey shows the continuity of patristic thought in a host of humanistic writers like Petrarch, Boccaccio (in particular in the De Genealogia), Erasmus, Vives, Salutati, and Guarino of Verona. In the conclusion there is a statement which surely cannot be counted among the great revelations: "Les quelques exemples, les quelques textes proposés confirment bien qu'on ne saurait parler de rupture absolue entre la culture médiévale et la culture humaniste" (p. 18).

Françoise Joukovsky (Rouen) has chosen a much more specific area and therefore she can go deeper in her investigation of "Plotin et la Renaissance:

*Études seiziémistes offertes a Monsieur le Professeur V.-L. Saulnier par plusieurs de ses anciens doctorants. Genève: Librairie Droz, 1980, Pp. ix, 425, Fr.s. 120.00 
Les références aux Ennéades dans quelques éditions de Platon et des Pères de l'Eglise." Among the latter, Saint Augustine contributes through two editions of De civitate dei while the works of Gregory of Nyssa are also important. Of special interest in this context are the commentaries on Plato by Ficino and Louis Le Roy, alongside the Vives commentary on the De civitate printed by Froben in 1552. Although Joukovsky avoids facile parallels between Plotinus and Ficino, being well aware of the differences underlined by $O$. Walzel, she makes clear that Ficino contributed widely to the editions of Platonic dialogues by the French humanist, while keeping the latter's understanding of the Florentine thinker within bounds: "[Le Roy] revoit le Banquet à travers le commentaire de Ficin, et il ne semble pas faire la distinction entre la pensée de Platon et le complément plotinien que Ficin lui avait apporté" (p. 27). Near the end of this penetrating study we find a summation that represents a perfect link with Béné's topic: "L'influence de Plotin semble souvent indirecte, à la fois soutenue et dissimulée par celle de Platon ou des Pères de l'Eglise. $\mathrm{Au} \mathrm{XVI}$ siècle comme au Moyen-Age, elle s'exerce en partie grâce à la littérature patristique" (p. 32). (A note: This article on Plotinus by F.J. runs alongside her "Plotin dans les editions et les commentaires de Porphyrie, Jamblique et Proclus à la Renaissance," $B H R, 42,2$ [1980, like the book], 387-400. Here and there the tracks converge.)

With Robert Aulotte (Paris-Sorbonne) we take another step from the general to the particular: "Sur une lettre de Jean Angeli, helléniste des années 20, éditeur des Hieroglyphica d'Horapollon." This letter, admittedly not unknown (see Herminjard, Michel François, Eugene F. Rice - not Engène!) is given here in full, with Aulotte's French translation next to the Latin original, which ushered in the first Greek printing of the Hieroglyphica in 1521-22 (this was in turn accompanied by a Latin translation). The interest of the letter lies, on the one hand, in its alliance of Egyptian hieroglyphics with the symbol of the Cross and "les mystères de notre SAUVEUR," which should remain properly inaccessible to uninitiated minds and gossipy tongues; on the other hand, we witness Angeli edging closer to the circle of Meaux and "le Trismégiste Lefebvre." A highlight is the compliment to the addressee, Jean de Mauléon, who introduced the writer to "la philosophie cardinalice," but this is immediately followed in the original by "immo fabrilis," thus alluding nicely to the contamination that was taking place.

"Démocrite et la Renaissance de la critique" by Jean Jehasse (SaintEtienne) forms a useful complement to the Screech-Calder article "Some Renaissance Attitudes to Laughter" in Humanism in France (ed. A.H.T. Levi). From the basic nucleus - happiness, laughter, in the case of Democritus, vs. sadness, tears, "life is a sorry game at best," in the case of Heraclitus many rays shoot out, illuminating certain authors (Erasmus, Rabelais, Pontus de Tyard) and certain works, like Laurent Joubert's Traité du Ris (1579), and in particular the first and second Dialogue du Democritic of Jacques Tahureau 
(1562), which is fully analyzed. "Le mythe de Démocrite fait ainsi saisir l'élaboration d'une critique mondaine, mais sérieuse, dont l'arme est le rire ... mais aussi ... une critique assimilée à une méthode scientifique" (p. 53). There is much that is new, or at the very least newly brought into focus, about the influence of Democritus on French humanistic criticism in the sixteenth century, mainly in the second half.

Marie-Madeleine de la Garanderie (Nantes) attempts a major, difficult subject, "L'Architecture textuelle à la Renaissance," but unfortunately she has built on sand. Eight pages might perhaps have been sufficient to do justice to one author. Here the sights are set on Budé's De asse and Montaigne's Essais, with an insufficient charpente to sustain either one. With the latter, Daniel Martin (unmentioned here) has come much closer to the mark in the Introduction to his edition (reproduction photographique) of the Essais in the original 1580 imprint (Slatkine-Champion, 1976). Martin mentions l'architecture again and again, and he shows us a blueprint that we may not want to follow along every line, but which is workable.

The second part of this hommage, "Aspects de la littérature narrative," is divided into 1. "Des Chroniques gargantuines à l'oeuvre de Rabelais" and 2. "Regards sur la nouvelle française." Roland Antonioli (Lyon-III) has the first turn with "Le motif de l'avalage dans les Chroniques gargantuines," an entertaining if rather hazardous trip down the gullets of various voracious giants, with various Gargantuan capacities. The Croniques examined here are mainly those in the libraries at Montpellier (Faculté de Médecine), Aix (Bibl. Méjanes), and Oxford (Bodleian). Of special interest is the discussion of Celtic antecedents, like Sugyn in the Mabinogion and the frequency of cannibalism in the Welsh tales, a theme for which the author refers us to Stith Thompson's famous Motif-Index. These early variations on the motif of l'avalage enrich our understanding of a New World, such as Rabelais fancied it in chapter XXXII of his Pantagruel.

"L'Enracinement de Pantagruel dans les genres médiévaux" is a minor tribute of two pages.

Jean Céard (Paris-XII), whose name has considerable resonance since the publication of his La Nature et les prodiges in 1977, writes about "L'Histoire écoutée aux portes de la légende: Rabelais, les fables de Turpin et les exemples de Saint Nicolas" (pp. 91-109). This is a painstaking search for the sources which seconded Rabelais when he staged the duel between Lougarou and Pantagruel and the ensuing death of Epistémon. The textual variants help us to give proper ascriptions to the fables and exemples mentioned in the title, although references to their authors are so isolated in Rabelais' work that one cannot argue for a major influence. The study meanders at times along byways overgrown with learning, between the texts with their stemmata, as it were, and Rabelais' broader intentions in their adoption for his story: "une parodie 
d'une certaine historiographie, profane et sacrée, qui est accusée de verser dans le roman" (p. 107). The didactic purpose leaves no room for levity and it may in fact be somewhat overstated.

G. Jeanneau (Université Catholique d'Angers) revisits the marriage counselors we know so well, in his "Rabelais et le mariage." He anthologizes the standard passages and then lists the parallels with Plutarch's Conjugalia praecepta (in Jehan Lodé's French translation of 1535), with a sprinkling of Erasmus here and there. It seems difficult to handle this subject without a single mention of Screech's The Rabelaisian Marriage, but this cannot cover up the fact that Jeanneau brings in Plutarch (on p. 115) with exactly the same passage chosen by Screech as his overture (p. 78). St. Paul expounded by Hippothadée is no stranger to Jeanneau, with the English scholar keeping a close watch.

In 1953 A. Krailsheimer pointed out in "The Andouilles of the Quart Livre" that "any interpretation which is to carry conviction must take into account all the various factors, linguistic, literary, historical ..." (François Rabelais quadricentennial vol., p. 232). "La Guerre des Andouilles: Pantagruel IV, 35-42" by Françoise Charpentier (Paris-VII) stresses the linguistic aspects, departing from the fact that "la guerre va s'engager exclusivement sur un incident langagier" (p. 121) or, to pick up the same field position on p. 128, "guerre de papier, bataille de mots." However, this is a present-day (winning) battle with linguistic problems: it ranges from onomastics to semantics, from diction to contradiction, from Plato to Beneviste, from signifiants to signifiés, from the unifying force of language and myth to the destructive force of the sexual ambivalence of the Andouilles. A deeper understanding of "structure interne ... mouvement ... sens" are the rewards of a new assessment of the modalities of expression. This is a very probing study where the modern perspective is not self-serving.

From Le Dessein de Rabelais (a rallying point for $\mathrm{F}$. Charpentier) we move on to "Le Dessein des Propos rustiques" by Gabriel A. Pérouse (Lyon-II). The author's thèse of 1974, Nouvelles françaises du XVI siècle: Images de la vie du temps (Genève, 1977; reprt. Lille, 1978) begins with an unusually felicitious expression of gratitude towards V.-L. Saulnier. In that work, Noël du Fail occupies an important chapter (pp. 311-41) with Les Contes et Discours d'Eutrapel, where clusters of rural houses and trees fill most of the landscape. The offshoot offered here supports the exordium, "Du Fail, aujourd'hui, retient l'attention." In a sense one could say that this is an "étude sur le temps humain" since Pérouse establishes five time strata which govern the structure of the Propos, ranging from the present, i.e., the moment of redaction, to the "bon vieux temps," very remote and of great length. At the core remains the perpetuation of the providential order, the "collation des aages," which still fits within the restricted dimensions of the "recueils 
'gigognes' (à encadrement)," as we see ably demonstrated - not only in the main text but also in the footnotes which combine (though less than in the author's thèse) cascades of information with a sense of humour.

A new, slightly askew pearl in the crown of "la Marguerite des Princesses" is "Fonds mythique et jeu des sens dans le 'Prologue' de l'Heptaméron" by Claude-Gilbert Dubois (Bordeaux-III). This is another meeting of "les anciens et les modernes," markedly leaning towards the latter, yet without kindling a "querelle." At every turn, the bark is stripped away to release the sticky sap underneath, beginning with Oisille who is not only an anagram for Loyse, but also, "par cryptage ... l'oiselle, la femme oiseau ... habitée par L'Esprit pur ... hantée par l'Azur" (p. 153). This "méthode de décryptage," this "jeu de masques" can be fascinating, but should it be boundless? There are protective question marks: "Longarine (Longue arène, long arine, longue narine?), Dagoucin (Dague au sein?), Saffredent (Dents longues?)” (p. 163). But let us not deprive the travellers and the adverse circumstances they encountered of their deeper meaning: "Marguerite de Navarre, tout en racontant une histoire réaliste de mésaventures dans les Pyrénées, écrit en soustexte une nouvelle Genèse, un nouvel épisode du déluge et de l'arche, un Pilgrim's Progress" (p. 167). Thus we are urged on to participate in this "triple lecture: littérale, allégorique, anagogique." Here and there along this route to salvation one wants to sit down, take a breather and lay down the staff. But the quest is too interesting to be abandoned.

"Des Périers et la communication: Proposition d'une lecture des Nouvelles Récréations" by Krystyna Kasprzyk (Warsaw) is an astute, careful probe of the subcutaneous lesions that break through the apparently carefree surface. The problem, so replete with parallels in modern thought, is "l'impossibilité des contacts humains" and "la non communication ... du langage" (pp. 172, 173). The author gives many examples of "cette comédie de l'incompréhension générale" and of "la syntaxe équivoque [qui] peut produire des conséquences funestes." Far from being ungenerous with searchers who have pointed the way, K.K. can well claim that "la lecture proposée ... jette un éclairage nouveau ... sur ce malaise, cette déception et cette amertume qu'y décèlent W. Pabst et L. Sozzi." This breakdown of communication is also examined briefly in the Cymbalum mundi and in Des Périers' poetry. N. Nurse, in his ed. of the Cymbalum seems to invoke the same "mournful numbers" that we find echoed in the pages at hand: "Tableau de la misère de l'homme," "Le pessimisme sévit dans la plupart des poésies de Bonaventure" (Nurse ed., p. xxiii). But it is here, not in Nurse, that we get a searching diagnosis of this anguish and misery, with the purported suicide mentioned only at the very end. It is never fashioned into an instrument for auscultation.

The next major rubric in the homage volume for V.-L. Saulnier deals with "Aspects de la poésie en France," divided into three groups which roughly follow a chronological order: 1. "De la Grande Rhétorique à la Pléiade," 2. 
"L’Age de la Pléiade," and 3. "Descendances." Marc-René Jung (Zurich) introduces us to a rather small, hitherto virtually unknown figure among the Grands rhétoriqueurs: "Maître Antitus, Rhétoriqueur." Actually, this modest versifier was put in the company of the "grands" on only one occasion, by Nicaise Ladam (on whom see H. Guy, I, 347-49). Antitus spent part of his life in ecclesiastical services in Lausanne and it is there that Jung has studied a pertinent manuscript of 38 leaves that had been only briefly noted before. It belongs to the very beginnings of the 16th century. One work is "La satyre Megere," most of which is merely a transcript of a Doleance de Megere of Regnaud Le Queux. In one of the borrowed dizains the author calls out "Reviendra l'on au noble eage doré?" Then there are three rondeaux and one ballad. These are followed by the most ambitious work, "Le portail du temple de Bocace," another déploration, in keeping with the propensities of the group. In this instance George(s) Chastelain lent more than one helping hand with his Le temple de Boccace. The ubi sunt motif (Bocace?, maistre George?, maistre Alain?, many others), called by Jung "une nouveauté de l'époque" (p. 188, n. 25) - but where is Villon? - contributes to several relatively fortunate huitains and dizains. The scholarship displayed is impeccable, but was it perhaps invested unwisely?

Claude Longeon (Sainte-Etienne) surprises us with the title of his study, "Maurice Scève, traducteur des Psaumes," since we rather think of Marot and Desportes in this capacity. However, no reader of Saulnier's Maurice Scève could claim ignorance since pp. 378-80 of vol. I are occupied by a section "Les Psaumes." It has been accepted so far that the two psalms translated by Scève (XXVI and LXXXIII) first appeared at the end of Trente psalmes de David par Gilles d'Avrigny, 1549. But there is an imperfect copy in the Vatican, printed by Etienne Dolet (the title page has been torn off and the name of Marot is inked over). Longeon does sure-handed detective work in assigning this imprint to the year 1542 . Scève allied by Dolet with the already reputed Marot - what a "merveilleuse "affiche'," as Longeon says, but naturally also one that could easily be boarded up. It is of great help that L. gives the complete text of the two psalms, with variants according to MS 2336 in the BN and the d'Avrigny text, printed by Guillaume Thibout. 1542 is preferable to 1549. The manuscript is based upon 1542. Did Scève merely follow the trend of turning biblical texts into French or were there personal reasons for this "religious episode" around 1541? This remains problematic. In these translations the poet did not indulge in any form of hermeticism. That the Latin orginal is amplified approximately threefold in an attempt to securely fix every meaning was surely not an isolated procedure at that time, but it reminds one so much of Marot's similar inflations that one wonders whether a direct influence could perhaps be established.

Lionello Sozzi (Turin) who has been the chef de file among Des Périers scholars practically since the appearance of this "thèse passionnante" (Henri 


\section{2 / Renaissance and Reformation}

Weber) on the Nouvelles Récréations et joyeux devis in 1965 gives us here a modestly titled "Remarques sur la poésie religieuse de Des Périers." This long and densely documented article can be linked with both Kasprzyk's and Longeon's studies: Sozzi also points out Des Périer's feelings of inadequacy with regard to his poetry, "il n'y voit qu'insuffisance et défaillance" (p. 205). And, like Longeon vis à vis Scève's rendition of two psalms, we are told that in Des Périers' transformation of biblical sources "il faut reconnaître que son amplificatio finit parfois par délayer et affaiblir la densité du texte original" (p. 215). The focus is on four poems drawn from the Old and the New Testaments, a "Cri touchant de trouver la bonne femme" and a "Cantique de Moyse;" then a "Cantique de la Vierge" and a "Cantique de Siméon" (both from St. Luke). Sozzi invites us to follow a truly stunning network of filiations of texts and critical interpretations, in a set of footnotes which on some pages reach almost Baylesque proportions. The principal pattern is to give first a line from the Vulgate and underneath the French translation of Lefèvre d'Etaples, followed by that of Olivetan (largely based on the former), and finally the verses of Des Périers. If the poet thought that two interpretations were possible, he gave them both. He leaned most heavily on Olivetan (Sozzi spells it Olivétan), especially in a "série très nombreuse de choix terminologiques et métaphoriques" (p. 214). Often the redundancy manifests itself in the use of adverbs. However, there are enough examples that show how the poet could effectively assert himself, as in the verses "L'estincelle dernière / De mes ternissans yeux ..." (see p. 220). In one area Des Périers has given an emphasis that far transcends any of his models: the accent on the dignity, even the majesty of man, an idea so frequently found in the writings of the humanists.

Geneviève Demerson, whose Thèse d'Etat de l'Université de Clermont-II (1979) dealt with Jean Dorat's Neo-Latin poetry, continues her work in the mainstream of classical scholarship as related to the French Renaissance with her "Dorat, commentateur d'Homère." This is another contribution one could call an editio princeps since the passages printed are drawn from a manuscript, in this instance notes taken by a student from lectures given by Dorat on the Odyssee and the Homeric Hymns. It was Kristeller who first called attention to this MS owned by the Ambrosiana, Milan. Mme Demerson establishes why these notes must have been taken between 1554 and 1571 , admittedly a wide span. The transcription offered at the end of the article occupies two pages and is of necessity fragmentary in nature. It deals with the beginning of Book X of the Odyssee, where Odysseus visits the floating Aeolian island, home of Aeolus, the King of the Winds who married his six sons ("intelligunt sex menses hybernos," as the student duly noted) to his six daughters ("totidem menses aestiuos qui foecunditatem mulierum imitantur"). There follows the disastrous episode of the hostile winds which the treacherous host handed over in a leather bag and which "Socii Vlyssis, qui stulti sunt, illo dormitante 
uentorum ligamina utre dissoluto demp serant ..." (p. 233), with the entire crew eventually being thrown back to where they had started. Mme Demerson is in full control of the situation, dividing Dorat's explications into three groups (naturelle, composite, historique), supplying not only corrections of detail, but also hidden contributions to Dorat's hermeneutics (Heraclitus, Plautus, Claudian, Boccaccio). "Cet auditeur est, en tout cas, un latiniste honorable." Geneviève Demerson surely is much more than that.

What's in a name? The onomastic lessons of C.-G. Dubois, which were mainly concerned with symbolism, are pushed to the edge of Mount Parnassus in "Poétique du nom dans Les Regrets" by Gisèle Mathieu-Castellani. The entire structural machinery is in full operation here, as is immediately apparent in the initial orientations on modification structurelle and modification fonctionnelle (éléments sémiques, dénotatifs et connotatifs, le signifié, le signifiant, le référent, etc.). There are useful interpretations of the poetic qualities of various names, the import of their position (beginning, middle or end) in a verse, and the "fonction émotive" whenever Du Bellay introduces himself. The poetic qualities of the "beaux noms," whether they be of persons (Scève, Avanson) or places (Rome) are given their proper luster. The going gets tougher when we reach the "processus de sémantisation du nom" (p. 250). Here we are taught how many possible meanings are hidden in RonsARD: "celui de difficulté ( $a r d=$ difficile, ardu), celui d'art ( = technique, métier des vers), celui de chaleur (arder = brûler)" (p. 252). By contrast, "Le Nom Dubellay a un contenu émotif bien différent de celui de Ronsard: il n'a guère ... de spectre sémique - sinon, peut-être le sème BEL (sème de la beauté), ou BELE (sème de la plainte) ... ou EL = AILE” (ibid., n. 45). Once again, we can see the Grands rhétoriqueurs nod approvingly.

However, I am sorry to report that the entire undertaking is seriously undermined by the dismal state of the quotations from Du Bellay. Where the individual word is of such paramount importance, it must be respected. First of all, the text used is not indicated, as if Du Bellay mattered less than Saussure \& Co. The small differences between Chamard and Jolliffe cannot alleviate the following - not counting "St tu m'en crois, Baïf," (p. 242) which can happen to anybody - "Veux tu sçavoir, Duthier ..." (Regrets LXXXII); in Chamard's ed.: "Veulx-tu sçavoir (Duthier)...." I refrain from listing about a dozen more similar cases, leaving punctuation aside. And I cannot fathom why the parentheses Du Bellay used so freely are categorically omitted. The poet does not use them when the person apostrophized occupies the initial position in a verse, nearly always when the name has moved "inside," especially when it is located at the end of the first hemistich (sauf erreur ou omission on my part). See the handling of (Belleau) in CXXXV and Jodelle in two positions in CLXXX. Are these divergences meaningless?

Calm after the storm: Claude Faisant's 'La 'Résurrection' de la Pléiade (Contribution à l'étude de la réception critique)." In measured strides the 


\section{4 / Renaissance and Reformation}

author covers the various fields of modern critical attitudes towards what used to be called the "fortunes" of an oeuvre. The shift from création to communication, the dialogue between the reader (or the critic) and the work (Barthes), the relationship between society and literature (Goldmann), the essentially objective (or subjective?) view of réception by members of the school of Prague, the effects of changing cultural horizons (school of Constance), these are just some of the areas covered by Faisant. This preamble to the Romantic period, Sainte-Beuve, and the renascence of Ronsard and the Pléiade is a bit long, occupying as it does more than two thirds of the total space. It is worthwhile to be reminded (if one knew) that Sainte-Beuve's judgment of Ronsard, as expressed in certain articles in the Globe, was originally very severe - "un pédant mitigé de classique." This rejection did not last. In the words of Faisant, "ce n'est qu'à la lumière des doctrines nouvelles de Hugo et du Cénacle sur l'autonomie de l'art qu'il peut enfin relire Ronsard dans un tout autre esprit" (p. 264). This revirement would hardly have been enough to sway Marcel Proust.

Guy Demerson (Clermont-Ferrand) turns his attention to Jean de la Gessée (1551-1596?), a Gascon poet who has twenty-seven entries, most of them pertaining to his original works, in A. Ciorancesco's Bibliographie de la littérature française du seizième siècle (1959), to which V.-L. Saulnier made such important contributions. To judge from the generous helping offered by Demerson, it is a pity that these viands have been withheld from us for so long, that is, if we can stand some hyperacidity. In his Jeunesses, a group of sonnets published in 1583, La Gessée, never indulging in self-adulation, says that "parfois la satyre enfielle son aigreur." Elsewhere in the Premières Euvres Françoises (nearly 1500 pp.) he calls himself "mal cault" and admits that his emotionalism easily makes him shoot "Ces traitz mordantz." This Gascon in whom we can easily detect some of the harshness and indiscretion of which Montaigne speaks - never minces words and freely lashes out at men and conditions, fates and fortunes. Ronsard's Discours "lui ont appris à déployer une période en alexandrins éloquents," but this does not shield le prince des poètes from the indignation of the epigone. Nor did Du Bellay, Dorat, Belleau, Peletier, Baiff, Jodelle, Jamyn, and Morel fare any better. Significant works are also the Discours poétiques and the Odes-Satyres (both 1579), the latter being an admixture which gave the poet the freedom of form and expression he was seeking. The range of satirical sallies, with Lucian, Juvenal, Ronsard, Du Bellay, Rabelais, and Berni among the prompters, is really quite impressive. Many of the caricatures show a sure, daring hand. But the somber accents predominate. Marcel Raymond says, "La Jessée [the other spelling] fait une étrange figure de persécuté; il a "couru longuement une très-cruelle fortune."' (L'Influence de Ronsard, II, 173 - R. allots ten pages to this disciple.) The personality we meet and M. Demerson's manner of presentation are arresting. 
The authority of M. Raymond is invoked again in the following study, "Agrippa d'Aubigné et du Bartas" by Jacques Bailbé (Caen). Raymond felt that "d'Aubigné compose son poème avec l'emportement farouche d'un fanatique," whereas the same brazen clang "ne résonne que de loin en loin dans les Semaines" (quoted on p. 290). Bailbé is in a quandary. He would like to establish proof of mutual influences between the two Protestant poets and, considering the similarities in themes, tonalities, and certain expressions, "on serait tenté ...," but by the time he has reached his conclusion he has not gained in assurance: "Les rapprochements que nous venons d'établir doivent nous inviter à la prudence au sujet des influences réciproques chez des poètes qui puisent à des sources communes. Mieux vaut essayer de surprendre leur originalité." The latter goal is reached in the four main divisions of the essay: I La muse chrétienne; II Le monde à l' envers (a topos already used by Ronsard in his Discours of 1562, as is pointed out); III L'inspiration biblique (obviously difficult to separate from I.), and IV Les images du baroque (a sketchy discussion, not much more than an appendage, with d'Aubigné easily holding the upper hand). An abundance of textual illustrations allows us to compare the two poets in the areas chosen by Bailbé. Among the bibliographical references, we must now add Yvonne Bellenger's edition of La Sepmaine (Texte de 1581), 2 vols., STFM, Paris, Nizet, 1981.

The fourth major section of these Etudes, bearing the title "Les Lettres à l'écoute du monde et des événements" offers considerable leeway, as is reflected in the subjects treated. Madeleine Lazard (Paris-Sorbonne) has written the most entertaining piece in this book, "Paris dans la comédie humaniste." It was perhaps inspired by a subsequently published talk V.-L. Saulnier gave at the Sorbonne in 1951, "Paris devant la Renaissance des lettres," the only secondary source mentioned - a graceful gesture. The substance of this guided tour through sixteenth-century Paris is drawn from about twenty-five comedies in the vernacular (a fact which may not be entirely clear from the title). Thus the footnotes refer only to passages in plays, e.g., the four mentioned on p. 317: Contens, V, 1; Neapolitaines, V, 1; “Avantjeu" des Esbahis; Corrivaus, IV, 2. This colorful gobelin required many careful stitches, obviously patterned after not only the plays chosen, but also studies of the Renaissance and present-day topography of Paris, records of trades and guilds, social customs of the times, the movements in and around the markets, and, of course, literature well beyond the confines of Lutetia. The completed, well-composed canvas permits us to "revivre l'animation de la foule parisienne" (p. 319).

Nicole Cazauran (E.N.S. de Sèvres) takes us back to the serious business of a country torn by strife in her "La 'Tragique peinture' du premier Dialogue du Réveille-Matin." One aspect of the Catholic-Huguenot confrontation was the intense pamphlet war, with thousands of salvos being fired by either side. Among these, the Réveille-Martin des François (1573), of undetermined 
authorship, occupies a special place in that it displays "une impartialité et une modération remarquables" (p. 331; also n. 17). N. Cazauran has difficulties in bringing her painting of the tragedy of St. Bartholomew into focus. J.W. Allen can help us to explain this: "The Réveille-Matin is a hotch-potch of ideas current among the Huguenots at the moment, unsystematically presented and all rather vague. It is, perhaps, especially remarkable in that the view presented was almost unconnected with any form of religion" (History of Political Thought in the 16th Century, p. 312). The accounts of the massacre are really more poignant in an equally adduced tract that was slightly earlier than - but not a source of - the Réveille-Matin, the Latin De Furoribus gallicis. N. Cazauran admits herself the "sécheresse relative" of the Réveille-Matin, and she has not been able to escape some of that dryness in her perfectly scholarly presentation. It must be said, however, that near the end of the pamphlet and the article the tempo quickens, aided by some sharp satirical thrusts against the Valois.

Jacques Pineaux (Lille), whose name we associate mainly with research in pamphlet literature, stays on the battlefields in his contribution, "Mort et transfiguration d'un héros: Blaise de Monluc à Rabastens." The Catholic assault on Rabastens, near Montauban, in July 1570 preceded the short-lived peace of Saint-Germain by less than two months. We can read in Monluc's Commentaires why and how he attacked and was badly wounded, yet he lived to tell the tale ("Pléiade" vol., pp. 771-84). Pineaux follows these events, but he examines the inward-looking hero rather than cannons and corpses. It is interesting, for instance, how the leader in combat has a dark premonition of his fate and how the realistic description of his brutally slashed face is tranquilized, as it were, by literary dressings that cannot possibly reflect the situation at hand. There is also a finely observed ambivalence in the words of the fallen defender of the Catholic cause, reflecting that Monluc had been wavering between the opposing camps during much of his life. One could say that Monluc transcends his own death by being able to write about it, thanks to his "incroyable résistance à la souffrance" (p. 349). Pineaux has brought out Monluc's qualities as a writer and invites further research on him.

"L' 'Hispanophilie' de Brantôme" by Etienne Vaucheret (Pau) must count among the lesser offerings. The assertion that Brantôme knew Spanish, claiming himself that he spoke it "fort friandement," a level of proficiency he was not able to maintain, really does not seem to matter a great deal. We smile when we see this condottiere put on the garb of a philologist, stumbling merrily through the fields of grass-roots etymology. In a more serious vein, he considered to enter the service of Philip II, flirting with treason. Apparently the author of the Rodomontades espagnoles (among his lesser-known works) was fascinated with the fierce Spanish pride. Perhaps we could even go so far as to say that Brantôme had a "“fixation' à l'Espagne, au sens où l'entendent 
les psychologues" (p. 365). The proofreading of this article should have been better (see, for instance, pp. 362 and 364).

Rather limited in scope is also André Thierry's (Besançon) "Les Vieillards dans l'Histoire universelle d'Agrippa d'Aubigné." We are reminded that old age (which would be middle age today) did not enjoy much respect during the Renaissance, with d'Aubigné himself contributing some merciless caricatures of old women in his early Printemps. By-passing Les Tragiques, save for a reference to the cruel victimization of old people in the "Misères" and the abject opportunism of the young, Thierry quickly reaches his announced topic by introducing a number of vieillards who distinguished themselves. Some continued to fight heroically for the Protestant cause (Agrippa's father Jean and Henri de Rohan), others expressed some of the author's more daring political and religious convictions under the cloak of anonymity. One of these - actually there were only two prominent ones - "se révéla être une sorte de prophète" (p. 375), which takes us back to Les Tragiques. In his own, remarkably vigorous old age, d'Aubigné, "le Ferme," quite naturally felt sympathy for others who were upright and valiant and whose mind and muscle were not enfeebled by the advancing years.

The last section of the Saulnier volume comprises three studies on Montaigne, the first of these being "Montaigne, la 'Librairie' et le 'Pays sauvage"” by Daniel Ménager (Paris-X). This is an essay that combines penetrating thought with excellent writing. We are far removed here from another inventory of Montaigne's collection of books or the use he made of them. Instead, Ménager paints a portrait of Montaigne moving within the confines of his study, meditating and writing, but looking out: "La 'librairie' de Montaigne s'oppose au monde environnant dans la mesure où elle est un ilôt de culture en 'pays sauvage', où personne autour de lui n'entend rien aux livres, au latin et à la science" (p. 386). The chateau ("'mille volumes autour de moy") and the countryside ("la sagesse muette qui se tient dehors") are pondered, but always as a continuous va-et-vient that puts the creative process into relief. I would like to quote also: "Il n'est pas suffisant de posséder un lieu, la librairie, où l'on puisse, selon la formule humaniste, rêver en paix parmi les livres. Il est même nécessaire de connaître autre chose pour revenir plus délicieusement à soi-même et retrouver son propre murmure" (p. 393). Ménager's "portrait" gains in vividness not only through the many quotations from the Essais but also through his engagement of the fine arts (Van Eyck, Carpaccio, Dürer's Melencolia I - nocturnal, brooding). One minor surprise: the author uses the A. Thibaudet ("Pléiade") edition of the Essais rather than the P. Villey text in the reissue and improvement of which V.-L. Saulnier played such an important role (P.U.F., 1965). The following article is based upon this edition.

In "Erôs et les muses dans Sur les vers de Virgile" by Géralde Nakam (Paris-III), facts and the imagination have a tendency to become entangled, 


\section{8 / Renaissance and Reformation}

while the author remains quite faithful to Montaigne's bigarrure. The crucial sentence from III, 5 must be "Je ne sçay qui a pu mal mesler Pallas et les Muses avec Venus, et les refroidir envers l'Amour; mais je ne voy aucunes deitez qui s'aviennent mieux, ny qui s'entredoivent plus" (Villey-Saulnier ed., p. 848). No question about the interdependence of love and poetry, but how are they interwoven by Pallas, of whom Montaigne says so little in the Essais? Which of her many attributes come into play here? Perhaps her armor-clad chastity, which Montaigne may have had in mind when he contrasted arid resistance with the much more alluring examples of the liberalities accorded by Venus?

The goddess of love is extolled by G. Nakam also in the realm of the fine arts, "à partir de la peinture par Virgile de l'étreinte de Vénus et de Vulcain" (p. 396). Doors are opened to a Musée imaginaire of paintings, frescoes, tapestries, even a ballet, forms of art one would hope were "familières aux dames et aux gentilhommes contemporains," but do they illuminate Montaigne who kept his inclinations towards the visual arts so carefully in the dark? We read, as if this were incontrovertible, "En amour, Montaigne est de l'Italie du Quattrocento." The conclusion of "Des vers de Virgile" is promising for the feminist cause, "De quoi enchanter Marie de Gournay!" (n. 20) ... and also G. Nakam who appropriately inserts this essai into the sixteenthcentury discussions on the role and rights of women (pro and con). But this is just one of the topics where the author is too ostentatious with references that mushroom in all directions and almost make one forget the root underneath. Did Montaigne think of Marguerite de Navarre when he mentions, among examples of excessive shyness, a lady who was very anxious that no one saw her eat her meals? Then again, "Montaigne prend-il simplement le contrepied des styles amoureux contemporains, intellectualisme estéthique (Desportes, etc.) ou angoisse et terreur ('baroque')?" (part of n. 5). Regretfully, one has to say that the main framework of "Altersreflexionen" (Hugo Friedrich) is detroyed in this discourse. Why should André Gide have "pleuré à chaudes larmes" (quoted by H.F.) over "le poème érotique qu'est Sur des vers de Virgile, poème de charme dans lequel Montaigne déploie toutes sortes de séductions" (p. 396)?

The last contributor to this homage volume, Michel Bideaux (Montpellier), puts new markers along a well-traveled route. His "La Description dans le Journal de voyage de Montaigne" (pp. 405-22) starts out by calling our attention to the likelihood - in the wake of C.B. Brush's article in RHLF, 1971 - that in the first part of the Journal the secretary was much more independent of " $M$. de Montaigne" than has been thought. Regardless, it remains a "texte au statut incertain." Not much is made of the fact that in Rome, for instance, where the ailing traveller "avoit envie de voir le pavé" he showed much less of an awareness of the great works of art than Goethe, whose deeply felt enthusiasm is allowed to express itself in the German 
original. (On this score, some credit should have been given to M. Bockelkamp, "Montaigne et Goethe en Italie," BSAM 12, 1967.)

With Bideaux as our travel guide, we reach crossings that are entitled " $\mathrm{La}$ description réticente" (M. saw no need to describe Venice, "les raretés de cete ville sont asses connues"); "Un espace à l'échelle humaine" (a strong awareness of landscapes, "un décor où vient s'inscrire la trace de l'activité humaine," p. 414); "Du morcellement à l' unitê" (much better cohesion in the second part than in the first, e.g., the secretary's Bologna vs. Montaigne's Milan); "La description éclatée" (M.'s aversion to static images, preference for "les spectacles dans leur mouvement dynamique tel qu'il est aperçu par l'observateur," p. 420). In a concluding section Bideaux stresses that for Montaigne the main concern is the narration of an experience, "la relation qui s'institue entre lui et les lieux visités." Near the end there is a quotation from Stendhal's Voyages en Italie which helps us to understand Montaigne's viewpoint: "Je n'entends pas dire ce que sont les choses, je raconte la sensation qu'elles me firent."

Thus ends our journey through the vast landscape of learning which V.-L. Saulnier knew so well, from its highest elevations to its hidden grottoes, the "province" through which he guided so many friends of the Renaissance. I myself would like to recall here a passage from the Introduction Saulnier wrote for his Du Bellay, l' homme et l'oeuvre: "Le combat de l'homme et de l'écrivain, on voit assez bien qu'il représente, à nos yeux, le véritable aspect humain de la partie qui se joue. Un aspect, à ses heures, pathétique et cruel. En marge de l'étude littéraire, qui fait du détachement un devoir, il est permis, particulièrement [en ce moment commémoratif], ... de donner une pensée de pure et simple sympathie à ce gentilhomme. ..." No doubt Saulnier's pupils were eager to contribute to a volume that would honour a man who could write with such wisdom and sensitivity. A brief return to the obituary written by Robert Aulotte allows us to give the last word to one of these disciples: "le savant, l'animateur, mais c'est aussi l'homme que nous voudrions évoquer ici, dans ce suprême adieu."

State University of New York at Buffalo 